\title{
Šviesos spektro sudèties ịtaka bulvių (Solanum tuberosum L.) stiebagumbių apikalinio dominavimo slopinimui
}

\section{Živilè Juknevičienè ${ }^{1}$,}

Giedrè Samuolien $\dot{e}^{2}$,

\section{Akvilè Viršilè²,}

\section{Pavelas Duchovskis ${ }^{1,2}$,}

\section{Egidija Venskutoniené ${ }^{1}$}

${ }^{1}$ Lietuvos žemès ūkio universitetas,

Studentu g. 11,

LT-53361 Akademija, Kauno r.

El.paštas: Zivile.Jukneviciene@lzuu.lt

${ }^{2}$ Augalu fiziologijos laboratorija, Lietuvos agrariniu ir mišku mokslu centro Sodininkystes ir daržininkystès institutas, Kauno g. 30,

LT-54333 Babtai, Kauno r.
Eksperimentai vykdyti Lietuvos agrarinių ir miškų mokslų centro Sodininkystės ir daržininkystės instituto Augalų fiziologijos laboratorijos fitotroniniame komplekse. Tirtas šviesos spektro sudèties poveikis sẻklinių bulvių stiebagumbių dygimui bei apikalinio dominavimo slopinimui. Bulvių stiebagumbiai tris savaites iki sodinimo švitinti kietakūnio apšvietimo komplekse, kurio moduliai sudaryti iš raudonos 638, papildytos mèlyna 445, raudona 660, raudona 669, tolimąja raudona 731 bei UV $385 \mathrm{~nm}$ šviesa, taip pat po fluorescencine lempa. Palyginamieji stiebagumbiai laikyti fitotrono kameroje be apšvietimo. Skirtinguose apšvietimo deriniuose bendras fotonų srauto tankis buvo palaikomas vienodame lygyje $\left(50 \mu \mathrm{mol} \mathrm{cm} \mathrm{cm}^{-2}\right)$. Eksperimento pabaigoje buvo vertinamas bendras bei skirtingose stiebagumbio dalyse sudygusių pumpurų skaičius, pumpurų spalva, stiebagumbio masè, sukauptų sacharidų kiekis apikaliniuose pumpuruose, apikalinių pumpurų zonose ir šoninèse zonose.

Nustatyta teigiama šviesos spektro sudèties įtaka bulvių stiebagumbių dygimui. Švitinti stiebagumbiai formavo trumpus, kompaktiškus pumpurus, tamsoje laikytų bulvių stiebagumbių pumpurai buvo šviesiai geltoni, ištįsę. Daugiausiai sudygusių pumpurų (94,40 \%) rasta, kai daiginimui naudotos raudonos 638, mèlynos 445 ir tolimosios raudonos $731 \mathrm{~nm}$ spalvų komponentès. Sudygusių pumpurų skaičius nustatytas 37,31 \% didesnis nei tamsoje laikytų (palyginamujjų) stiebagumbių. Dèl pagrindinių raudonų 638 ir 669 su mèlyna $445 \mathrm{~nm}$ komponenčiu it takos buvo nustatytas didžiausias stiebagumbių apikalinio vyravimo slopinimas.

Neigiamas poveikis stiebagumbių dygimui nustatytas, kai apšvietimo derinys raudonos $638 \mathrm{~nm}$, raudonos $669 \mathrm{~nm}$, tolimosios raudonos $731 \mathrm{~nm}$ bei mèlynos $445 \mathrm{~nm}$ papildytas UV $385 \mathrm{~nm}$ (L7). Sudygusių pumpurų skaičius buvo 10 \% mažesnis nei tamsoje laikytų stiebagumbių.

Didesni sacharidų kiekiai apikaliniuose pumpuruose nustatyti tų stiebagumbių, kurie buvo laikyti tamsoje, kadangi $\mathfrak{i}$ juos asimiliatų transportas buvo intensyvesnis nei $\mathfrak{i}$ šoninius. Nustatyta, kad sacharidų kiekis pumpuruose bei pumpurų zonose didèjo dèl dygimo intensyvumo.

Raktažodžiai: bulvès, stiebagumbiai, apšvietimo deriniai, apikalinis dominavimas, pumpurai, sacharidai

\section{IVADAS}

Nepaisant to, kad bulvès yra tradicinis augalas Lietuvoje, bulvininkystè nèra intensyvi žemès ūkio šaka. Bulvès dažniausiai auginamos mažai paisant jų biologijos, dèl to bulvių derliai nèra dideli (2008-2009 m. vidutinis derlius 14,4 t ha ${ }^{-1}$ ) (Rodiklių..., 2010). Viena mažo derlingumo priežasčių - netinkama arba prasta sẻklinių bulvių stiebagumbių kokybè. Bulvių - sudètingo pagal fiziologiją augalo - augimo, vystymosi bei laikymo sąlygos turi ịtakos jų dygimui. Bulvès stiebagumbyje akelès išsidèsčiusios spiralès forma, kurių didžiausias kiekis sutelktas viršūninèje stiebagumbio dalyje (Allen, O’Brien, Firman, 1992). Kiekvienoje akelëje natūraliai yra trys pumpurų užuomazgos, iš kurių pirmiausia dygsta tik labiausiai išsivystęs. Kiti pumpurai dygsta tik pašalinus (pvz., nulaužus) vyraujanti pumpurą (Shpaar, Bykin, Dreger i dr., 2004).

Baigiantis ramybès būsenai, stiebagumbių akelèse pasirodo pumpurai. Pirmiausia dygsta viršūninè akelè - tai apikalinio dominavimo pasekmè. Šio reiškinio esmè tai, 
kad viršūninio pumpuro gaminami auksinai juda žemyn (bazipetaliai) ir kitų stiebagumbio pumpurų dygimas blokuojamas. Pasodinus stiebagumbius apikalinio dominavimo periodu tikètina, kad bulvès keras išaugins tik vieną stiebą. Daugelis autorių nurodo tiesioginị kero stiebų skaičiaus ir derliaus ryši (O'Brien, Allen, 1992). Apikalinio dominavimo periodo trukmė labai priklauso nuo bulvių veislès savybių, laikymo sąlygų (Grigoriadou, Leventakis, 1999).

Dygstant bulvių stiebagumbiams, asimiliatai intensyviai juda iš stiebagumbio i pumpurus. Sacharidai, atsakingos už signalo perdavimą molekulès, turi ịtakos augalams visuose vystymosi tarpsniuose - nuo dygimo iki brandos (Samuolienė, Šikšnianienè, Duchovskis ir kt., 2004). Tirpūs angliavandeniai, ypač gliukozė ir fruktozè, turi didelę itaką augalo generatyvinių struktūrų formavimuisi ir ląstelių bei viso augalo organizmo metabolizmui. Aplinkos sąlygos veikia asimiliatų judèjimą ir pasiskirstymą augale (Hare, Cress, Van Staden, 1999).

Sèklinių bulvių stiebagumbių dygimas - vienas svarbiausių veiksnių, nulemiančių skaičiu stiebų, kurie yra derlių limituojantis faktorius (Allen, O’Brien, Firman, 1992). Literatūros duomenimis (Lazauskas, Ražukas, 2001), geriausia bulves daiginti natūraliomis šviesos sąlygomis, ne aukštesnèje nei $17{ }^{\circ} \mathrm{C}$ temperatūroje, 35-45 dienas iki sodinimo, tuomet jų daigai būna trumpi ir stiprūs.

Šviesa - vienas svarbiausių veiksnių augalų augimui ir vystymuisi (Schuerger, Brown, Stryjewski, 1997; Lin, 2002; Urbonavičiūtè, Pinho, Samuolienè ir kt., 2007; Samuoliene, Šabajevienè, Urbonavičiūtè ir kt., 2007; Brazaitytė, Duchovskis, Urbonavičiūte ir kt., 2009). Tyrimais nustatyta, kad raudona šviesa yra svarbiausia augalų augimui, vystymuisi, fotosintezės aparato veiklai, morfogenezei (Furuya, 1993). Mèlyna šviesa daro didelị poveikị žiotelių atsidarymui ir fotomorfogenezei (Schuerger, Brown, Stryjewski, 1997; Dougher, Bugbee, 1998; Heo, Lee, Chakrabarty, 2002). Teigiama, kad fotofiziologiniai procesai vyksta normaliai, kai apšvitoje mèlynoji spektro dalis (nuo 440 iki $460 \mathrm{~nm}$ ) sudaro $10 \%$ energijos, o raudonoji dalis (nuo 600 iki $800 \mathrm{~nm})-90 \%$. Pastarojoje dalyje apie $75 \%$ energijos turi tekti spinduliuotei, kurios bangų ilgiai yra nuo 600 iki $700 \mathrm{~nm}$, ir apie $25 \%$ energijos turi tekti spinduliuotei, kurios bangų ilgiai yra nuo 700 iki $800 \mathrm{~nm}$. Taip pat žinoma, kad trumpesnių už $400 \mathrm{~nm}$ bangų ilgių spinduliuotè nepalankiai veikia augalų morfogenezès procesus, o ilgesnių už $800 \mathrm{~nm}$ bangų ilgių spinduliuotè kelia augalų temperatūrą ir kenkia jų produktyvumui (Bliznikas, Breive, Tamulaitis, 2004). Derinant šviesos spektrą galima sèkmingai valdyti fitohormonų sintezę (Samuolienė, Šikšnianienė, Duchovskis ir kt., 2004). Tai sudaro prielaidas ir augalų apikalinio dominavimo valdymui.

Darbo hipotezė - derinant šviesos spektro sudèties kombinacijas, slopinti apikalinį dominavimą bei paskatinti bulvių stiebagumbių dygimą.

Darbo tikslas - nustatyti šviesos spektro sudeties ịtaką bulvių stiebagumbių dygimui, apikalinio dominavimo slopinimui, sacharidų kiekiui bulvių stiebagumbių pumpuruose bei pumpurų zonose.

\section{TYRIMŲ METODAI IR SĄLYGOS}

Tyrimai atlikti 2008 m. Lietuvos agrarinių ir miškų mokslų centro Sodininkystės ir daržininkystès instituto Augalų fiziologijos laboratorijos fitotroniniame komplekse.

Bulvių stiebagumbiai tris savaites iki sodinimo daiginti fitotrono kameroje, naudojant skirtingų bangos ilgių kietakūnị apšvietimą bei fluorescencines lempas (F). Palyginamieji stiebagumbiai laikyti fitotrono kameroje be apšvietimo (K0) (1 lentelè).

Visuose apšvietimo deriniuose pagrindinè raudona spektro komponente, bangos ilgis - $638 \mathrm{~nm}$ (AlGaInP LED (LUXEON $^{\circledast}$ III Star, LXHL-LDE3C, Philips Lumileds Lighting Company) papildyta mèlyna $445 \mathrm{~nm}$ (LUXEON ${ }^{\circledR}$ III Star, LXHL-LB3C, Philips Lumileds Lighting Company), raudona $669 \mathrm{~nm}$, raudona $660 \mathrm{~nm}$, tolimąja raudona $731 \mathrm{~nm}$ bei UV 385 nm (i-LED, NCCU033T, Nichia Corporation, Japan).

Fotoperiodas - $12 \mathrm{~h}$, bendras apšvietimo srautas - $50 \mu \mathrm{mol} \mathrm{m}{ }^{-2} \mathrm{~s}^{-1}$. Palaikoma temperatūra $(\mathrm{D} / \mathrm{N})$ apie $17^{\circ} \mathrm{C}$. Spektro srautas matuotas radiometru (HR4000, Ocean Optics Inc., JAV). Tyrimai atlikti pagal schemą (1 lentelè).

\section{1 lentelè. Apšvietimo deriniai ir fotonų srauto tankiai}

\section{Table 1. Lighting combinations and photon flux densities}

\begin{tabular}{|c|c|c|c|c|c|c|c|c|}
\hline \multirow{2}{*}{$\begin{array}{l}\text { Eilès Nr. } \\
\text { Serial } \\
\text { number }\end{array}$} & \multirow{2}{*}{$\begin{array}{l}\text { Apšvietimo } \\
\text { derinys } \\
\text { Combination of } \\
\text { lighting }\end{array}$} & \multicolumn{7}{|c|}{ Fotonų tankio srautas \% / Flux density, \% } \\
\hline & & $\begin{array}{l}\text { fluorescencinè } \\
\text { lempa } \\
\text { fluorescent lamp }\end{array}$ & $\begin{array}{l}\text { mèlyna } \\
\text { blue } \\
445 \mathrm{~nm}\end{array}$ & $\begin{array}{c}\text { raudona } \\
\text { red } \\
638 \mathrm{~nm}\end{array}$ & $\begin{array}{c}\text { raudona } \\
\text { red } \\
669 \mathrm{~nm}\end{array}$ & $\begin{array}{c}\text { raudona } \\
\text { red } \\
660 \mathrm{~nm}\end{array}$ & $\begin{array}{c}\text { tolimoji raudona } \\
\text { far red } \\
731 \mathrm{~nm}\end{array}$ & $\begin{array}{c}\text { UV } \\
385 \mathrm{~nm}\end{array}$ \\
\hline 1. & KO & - & - & - & - & - & - & - \\
\hline 2. & LO & 100 & - & - & - & - & - & - \\
\hline 3. & L1 & - & - & 100 & - & - & - & - \\
\hline 4. & $\mathrm{~L} 2$ & - & 16 & 84 & & & & \\
\hline 5. & L3 & - & 16 & 81 & - & - & 3 & - \\
\hline 6. & L4 & - & 16,4 & 80 & 3,6 & - & - & - \\
\hline 7. & L5 & - & 16,4 & 78 & 3,6 & - & 2 & - \\
\hline 8. & L6 & - & 16 & 78 & - & 3,6 & 2,4 & - \\
\hline 9. & L7 & - & 16 & 73,6 & 3,6 & - & 2,4 & 4,4 \\
\hline
\end{tabular}


Tyrimams pasirinkta maistinès paskirties, vidutinio ankstyvumo bulvių veislè 'Solara'. Sèklinè medžiaga gauta iš Kauno augalų veisliu tyrimo stoties.

Stiebagumbiai suskirstyti frakcijomis: $<40$ g; $40-80$ g; $>80$ g. Stiebagumbių skaičius visuose poveikio deriniuose buvo vienodas - po 106 vnt. Eksperimentas atliktas trimis pakartojimais. Stiebagumbiai sunumeruoti, pasverti, suskaičiuotos akelès viršutinëje, vidurinëje bei apatinëje dalyse. Nustatoma: sudygusių pumpurų skaičius (vnt. ir \%) viršutinëje, vidurinëje bei apatinëje stiebagumbio dalyse, masè (g ir \%, tikslumas $\pm 0,001 \mathrm{~g}$ ). Monosacharidų ir disacharidų ekstrakcija atlikta sutrinant $\sim \mathrm{g}$ augalinės žaliavos keraminèje grūstuvèlèje, užpilant $4 \mathrm{ml}$ karšto bidistiliuoto vandens ir po $24 \mathrm{~h}$ nufiltruojant celiulioziniu ir membraniniu filtrais. Analizė atlikta efektyviosios skysčių chromatografijos metodu su refrakcijos indekso detektoriumi (Shimadzu, Japonija), Adsorbosil $\mathrm{NH}_{2}$ (150 x 4,6 mm) kolonèle (Alltech, Vokietija). Judrioji fazè: 75/25 acetonitrilas / bidistiliuotas vanduo.

Tyrimų duomenų vidurkio standartinis nuokrypis apskaičiuotas pagal programą „MS Excel“. Tyrimų duomenys ịvertinti dispersinès analizès metodu taikant Dunkano testą. Eksperimento duomenų statistiniam įvertinimui naudotas statistinis programu paketas „Selekcija“, jo programos ANOVA (Tarakanovas, Raudonius, 2003). Straipsnyje vartoti simboliai: $R_{05}$ - mažiausia esminio skirtumo riba esant 95 tikimybès lygiui. $S \bar{x}$ - vidurkio vidutinè kvadratiné paklaida. Sudygimas skaičiuojamas nuo pirminio akeliu skaičiaus ir išreiškiamas procentais.

\section{REZULTATAI IR JŲ APTARIMAS}

Stiebagumbiai, daiginti po kietakūnio apšvietimo bei fluorescencinès lempos moduliais, formavo trumpus, kompaktiškus pumpurus. Bulvių stiebagumbių, laikytų tamsoje, pumpurai buvo ištįsę bei šviesiai geltoni (K0), pumpurų sudygo vos $57,59 \%$ pirminio akelių skaičiaus (2 lentelè). Daugiausia sudygusių pumpurų nuo pirminio akelių skaičiaus - 94,40 \% (L3) nustatyta, kai daiginimui buvo naudoti trijų bangos ilgių šviesos diodai: $81 \%$ sudarẻ raudona $638 \mathrm{~nm}, 16 \%$ mèlyna $445 \mathrm{~nm}, 3 \%$ tolimoji raudona $731 \mathrm{~nm}$ komponentes, atitinkamai palyginus su fluorescencinès lempos poveikiu (L0) ir su tamsoje laikytais stiebagumbiais (K0). Nežymiai mažesnis (sudygo 91,25-92,21 \% akelių) poveikis nustatytas, kai stiebagumbių daiginimo apšvietimui naudotos dvi pagrindinès komponentes: raudona $638 \mathrm{~nm}$ bei raudona su mèlyna $445 \mathrm{~nm}$ (L1, L2).

Nepalankiai bulvių stiebagumbių dygimą paveikè spektrinę sudèti papildžius trumpaisiais $385 \mathrm{~nm}$ UV spinduliais (L7). Nustatyta, kad sudygo vos daugiau negu pusè pumpurų nuo pirminio akelių skaičiaus (51,61 \%), t. y. $10 \%$ mažiau, nei tamsoje daigintuose stiebagumbiuose (K0) (2 lentelè).

Pagal akelių išsidèstymą, bulvès stiebagumbiai suskirstyti $\mathfrak{i}$ tris dalis. Viršutinè stiebagumbio dalis, kurioje sutelktas didžiausias akelių skaičius, vidurinè ir apatiné, kurioje yra stolono prisegimo vieta (Šlapakauskas, Duchovskis, 2008).

2 lentelè. Šviesos spektro sudèties poveikis bulvių stiebagumbių dygimui $2008 \mathrm{~m}$.

Table 2. Effect of light spectral composition on potato tuber germination, 2008

\begin{tabular}{|c|c|c|c|}
\hline $\begin{array}{l}\text { Apšvietimo derinys } \\
\text { Combination of lighting* }\end{array}$ & $\begin{array}{l}\text { Vidutinis akelių skaičius gumbe } \\
\text { prieš daiginimą vnt. } \\
\text { Average eye number per tuber } \\
\text { before sprouting, units }\end{array}$ & $\begin{array}{l}\text { Vidutinis pumpurų skaičius gumbe } \\
\text { po daiginimo vnt. } \\
\text { Average bud number per tuber after } \\
\text { sprouting, units }\end{array}$ & $\begin{array}{l}\text { Pumpurų skaičius } \% \\
\text { Bud number, } \%\end{array}$ \\
\hline $\mathrm{KO}$ & 9,03 & 5,20 & 57,59 \\
\hline LO & 7,10 & 6,47 & 90,13 \\
\hline L1 & 7,20 & 6,57 & 91,25 \\
\hline L2 & 8,60 & 7,93 & 92,21 \\
\hline L3 & 6,67 & 6,33 & 94,90 \\
\hline L4 & 7,07 & 5,53 & 78,22 \\
\hline L5 & 8,07 & 5,83 & 72,24 \\
\hline L6 & 7,70 & 6,23 & 80,91 \\
\hline L7 & 9,30 & 4,80 & 51,61 \\
\hline $\boldsymbol{R}_{05}$ & & & 1,55 \\
\hline$S \bar{X}$ & & & $\pm 0,53$ \\
\hline
\end{tabular}

* K0 - kontrolè, laikyta tamsoje; L0 - fluorescencinè lempa; L1 - raudona $638 \mathrm{~nm} ; \mathrm{L} 2$ - mèlyna $445 \mathrm{~nm}+$ raudona $638 \mathrm{~nm}$; L3 - mèlyna $445 \mathrm{~nm}+$ raudona $638 \mathrm{~nm}+$ tolimoji raudona $731 \mathrm{~nm}$; L4 - mèlyna $445 \mathrm{~nm}$ + raudona $638 \mathrm{~nm}$ + raudona $669 \mathrm{~nm} ; \mathrm{L5}$ - mèlyna $445 \mathrm{~nm}$ + raudona $638 \mathrm{~nm}$ + raudona $669 \mathrm{~nm}$ + tolimoji raudona $731 \mathrm{~nm}$; L6 - mèlyna $445 \mathrm{~nm}$ + raudona $638 \mathrm{~nm}$ + raudona $660 \mathrm{~nm}$ + tolimoji raudona $731 \mathrm{~nm} ; \mathrm{L} 7$ - mèlyna $445 \mathrm{~nm}$ + raudona $638 \mathrm{~nm}$ + raudona $669 \mathrm{~nm}$ + tolimoji raudona $731 \mathrm{~nm}+$ UV $385 \mathrm{~nm}$

* KO - control, without lighting; LO - fluorescent lamp; L1 - red $638 \mathrm{~nm} ; \mathrm{L} 2$ - blue $445 \mathrm{~nm}+$ red $638 \mathrm{~nm} ; \mathrm{L3}$ - blue $445 \mathrm{~nm}+$ red $638 \mathrm{~nm}+$ far red $731 \mathrm{~nm} ; \mathrm{L} 4$ - blue $445 \mathrm{~nm}+$ red $638 \mathrm{~nm}+$ red $669 \mathrm{~nm} ; \mathrm{L} L$ - blue $445 \mathrm{~nm}+$ red $638 \mathrm{~nm}+$ red $669 \mathrm{~nm}+$ far red $731 \mathrm{~nm} ; \mathrm{L} 6$ - blue $445 \mathrm{~nm}+$ red $638 \mathrm{~nm}+$ red $660 \mathrm{~nm}+$ far red $731 \mathrm{~nm} ; \mathrm{L} 7 \mathrm{-blue}$ $445 \mathrm{~nm}+$ red $638 \mathrm{~nm}+$ red $669 \mathrm{~nm}+$ far red $731 \mathrm{~nm}+$ UV $385 \mathrm{~nm}$ 
Didžiausias teigiamas poveikis bulvių stiebagumbių apikalinio dominavimo slopinimui - sudygusių pumpurų skaičius: $45 \%$ viršutinèje, $43 \%$ vidurinèje bei $11 \%$ apatinèje stiebagumbių dalyse, kur panaudotas raudonų $638 \mathrm{~nm}$ ir $669 \mathrm{~nm}$ bei mèlynos $445 \mathrm{~nm}$ spalvų apšvietimo derinys (L4). Kai kurios šviesos spektrinès sudèties deriniai (L3, L6, L7) slopino bulvių stiebagumbių apikalinị dominavimą, apatinèje gumbo dalyje sudygusių pumpurų skaičius siekè 8-11 \% (1 pav.). Apšvietimo deriniai, papildyti raudonų $669 \mathrm{~nm}, 660 \mathrm{~nm}$, tolimosios raudonos $731 \mathrm{~nm}$ ir UV $385 \mathrm{~nm}$ (L7), inicijavo tolygesni stiebagumbių pumpurų dygimą. Vidurineje ir apatineje stiebagumbių dalyse sudygo apie 50 \% pumpurų nuo bendro akelių skaičiaus.

Pradejus dygti pumpurams, stiebagumbio energija išeikvojama: stiebagumbis vysta, mažèja jo masė (Shpaar, Bykin, Dreger i dr., 2004). Ivertinus stiebagumbių masę prieš daiginimą ir po jo, nustatyta, kad daugiausiai pumpurų išauginusių stiebagumbių (L3) masė sumažèjo labiausiai (2 pav.).

Dygstant pumpurams, cukrūs intensyviau persiskirsto iš stiebagumbio pumpuro zonos audinių ì patị pumpurą (Fernie, Willmitzer, 2001). Siekiant ịvertinti cukrų pasiskirstymą esant apikalinių pumpurų dominavimui ir ji slopinant, tirtas sacharidų kiekis daigintų stiebagumbių apikaliniuose pumpuruose, pumpurų zonose ir šoninių pumpurų zonose.
Bulvių stiebagumbius veikiant skirtingo apšvietimo deriniais, sacharidų kiekis pumpuruose bei pumpurų zonose priklausè nuo dygimo intensyvumo. Daugiausia sacharidu (30 $\mathrm{mg} \mathrm{g}^{-1}$ ) (ypač gliukozès) apikaliniuose pumpuruose sukaupe tamsoje laikyti (K0) stiebagumbiai bei L7 poveikio derinyje, kur pagrindinès mèlyna $445 \mathrm{~nm}$, raudona $638 \mathrm{~nm}$, raudona $669 \mathrm{~nm}$, tolimoji raudona $731 \mathrm{~nm}$ komponentès papildytos UV $385 \mathrm{~nm}$ spinduliais (3 lentelè). Šio poveikio metu bendras sacharidų kiekis apikaliniuose pumpuruose nustatytas $20 \mathrm{mg} \mathrm{g}^{-1}$. Nustatyta, kad raudonų 638 ir $669 \mathrm{~nm}$, mèlynos $445 \mathrm{~nm}$ (L4), taip pat mèlynos $445 \mathrm{~nm}$, raudonos $638 \mathrm{~nm}$ ir tolimosios raudonos $731 \mathrm{~nm}$ šviesos (L3) spektro sudètis, inicijavo tolygų stiebagumbių pumpurų dygimą (3 lentelè) bei sacharidų pasiskirstymą tarp apikalinių ir šoninių zonų.

Esant ryškiam apikalinių pumpurų dominavimui, apikalinių pumpurų zonoje nustatyta reikšmingai daugiau (10,05 ir 14,61 $\mathrm{mg} \mathrm{g}^{-1}$ ) cukrų (L2, L5) nei dygstant šoniniams pumpurams. Visgi šviesos spektro suděčiai veikiant fitochromo veiklą (Samuolienė, Šikšnianienė, Duchovskis ir kt., 2004), apikalinis dominavimas tirtomis sąlygomis nebuvo visiškai eliminuotas - $\mathfrak{i}$ apikalinius pumpurus asimiliatų transportas buvo intensyvesnis nei it šoninius.

Šviesos spektro sudeties poveikis tirtas daugelio augalų augimui, fotosintezès aparato veiklai, sausųjų me-

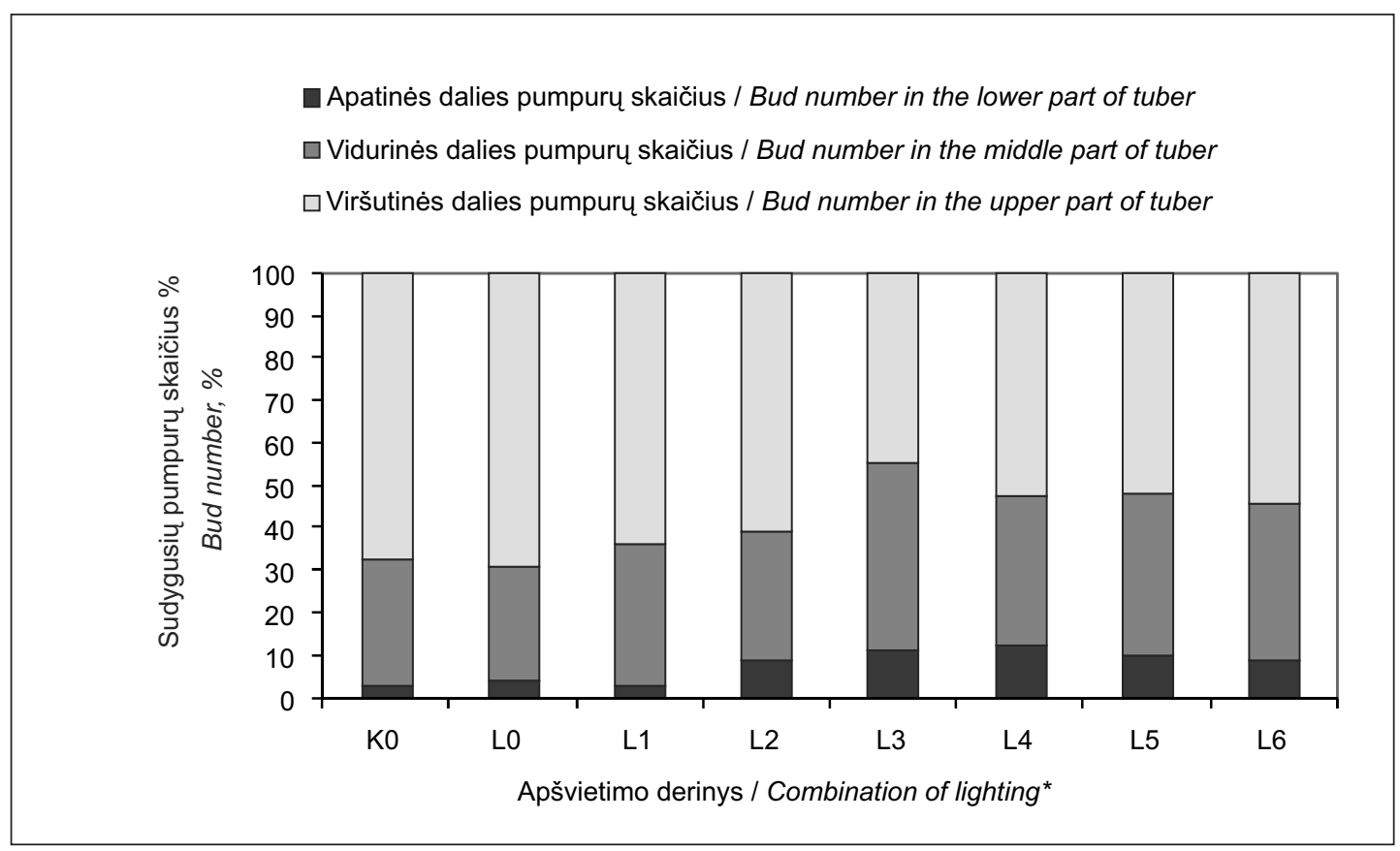

* K0 - kontrolè, laikyta tamsoje; L0 - fluorescencinè lempa; L1 - raudona $638 \mathrm{~nm}$; L2 - mèlyna $445 \mathrm{~nm}$ + raudona $638 \mathrm{~nm}$; L3 - mèlyna $445 \mathrm{~nm}$ + raudona $638 \mathrm{~nm}$ + tolimoji raudona $731 \mathrm{~nm} ; \mathrm{L} 4$ - mèlyna $445 \mathrm{~nm}$ + raudona $638 \mathrm{~nm}$ + raudona $669 \mathrm{~nm} ; \mathrm{L} 5$ - mèlyna $445 \mathrm{~nm}$ + raudona $638 \mathrm{~nm}$ + raudona $669 \mathrm{~nm}$ + tolimoji raudona $731 \mathrm{~nm}$; L6 - mélyna $445 \mathrm{~nm}$ + raudona $638 \mathrm{~nm}$ + raudona $660 \mathrm{~nm}$ + tolimoji raudona $731 \mathrm{~nm}$; L7 - mèlyna $445 \mathrm{~nm}$ + raudona $638 \mathrm{~nm}$ + raudona $669 \mathrm{~nm}$ + tolimoji raudona $731 \mathrm{~nm}$ + UV $385 \mathrm{~nm}$

* KO - control, without lighting; LO - fluorescent lamp; L1 - red 638 nm; L2 - blue $445 \mathrm{~nm}+$ red $638 \mathrm{~nm} ; \mathrm{L} 3$ - blue $445 \mathrm{~nm}+$ red $638 \mathrm{~nm}+$ far red $731 \mathrm{~nm}$; $L 4$ - blue $445 \mathrm{~nm}+$ red $638 \mathrm{~nm}+$ red $669 \mathrm{~nm} ; \mathrm{L} 5$ - blue $445 \mathrm{~nm}+$ red $638 \mathrm{~nm}+$ red $669 \mathrm{~nm}+$ far red $731 \mathrm{~nm} ; \mathrm{L} 6$ - blue $445 \mathrm{~nm}+$ red $638 \mathrm{~nm}+$ red $660 \mathrm{~nm}+$ far red $731 \mathrm{~nm} ; \mathrm{L7}-$ blue $445 \mathrm{~nm}+$ red $638 \mathrm{~nm}+$ red $669 \mathrm{~nm}+$ far red $731 \mathrm{~nm}+$ UV $385 \mathrm{~nm}$

1 pav. Šviesos spektro sudèties poveikis bulvių stiebagumbių pumpurų dygimui skirtingose stiebagumbio dalyse $2008 \mathrm{~m}$.

Fig. 1. Effect of light spectral composition on potato tuber sprout germination in different parts of tuber, 2008 


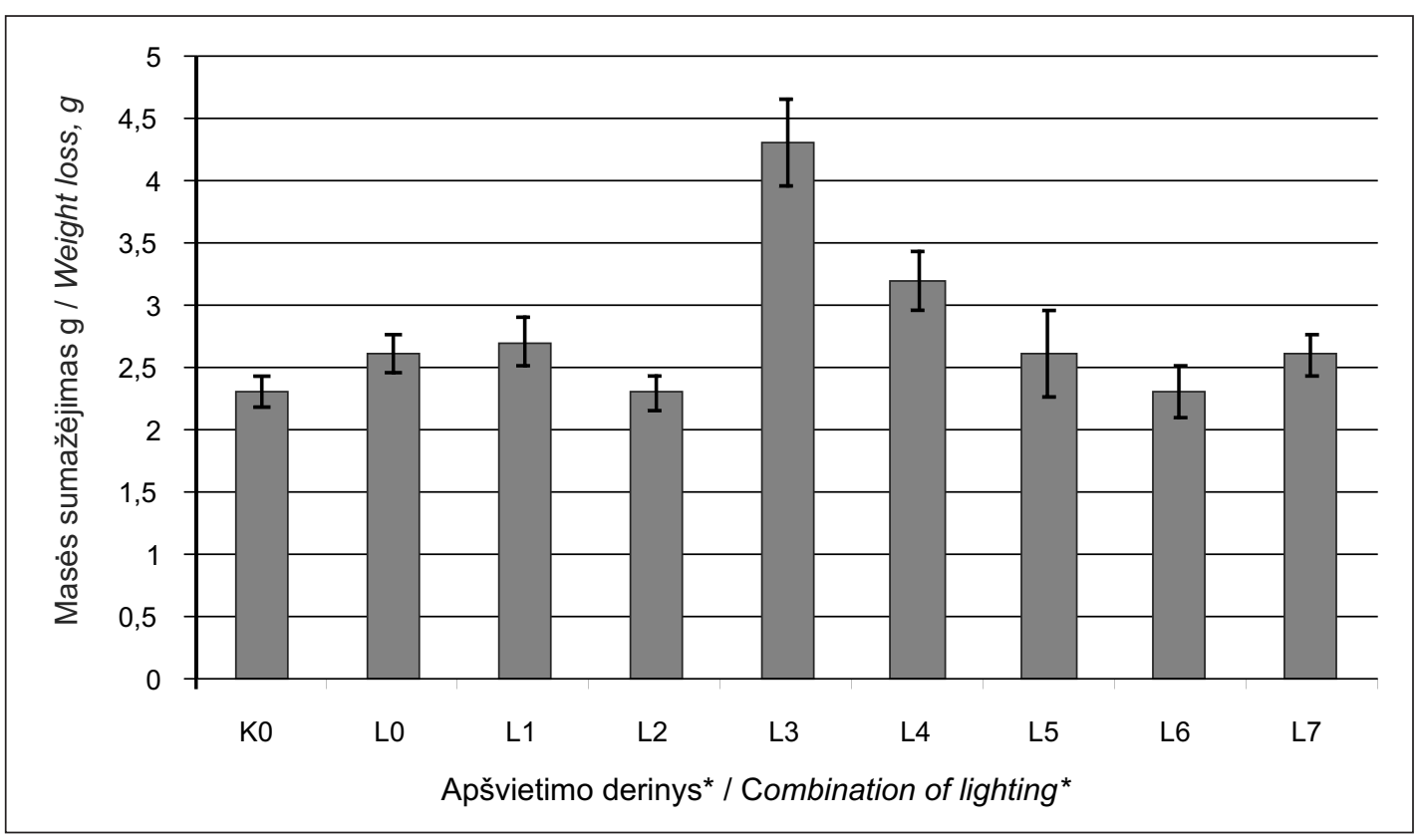

\footnotetext{
* K0 - kontrolè, laikyta tamsoje; L0 - fluorescencinè lempa; L1 - raudona 638 nm; L2 - mèlyna $445 \mathrm{~nm}$ + raudona 638 nm; L3 - mèlyna $445 \mathrm{~nm}$ + raudona $638 \mathrm{~nm}$ + tolimoji raudona $731 \mathrm{~nm} ; \mathrm{L} 4$ - mèlyna $445 \mathrm{~nm}$ + raudona $638 \mathrm{~nm}$ + raudona $669 \mathrm{~nm} ; \mathrm{L} 5$ - mélyna $445 \mathrm{~nm}+$ raudona $638 \mathrm{~nm}$ + raudona $669 \mathrm{~nm}$ + tolimoji raudona $731 \mathrm{~nm}$; L6 - mèlyna $445 \mathrm{~nm}$ + raudona $638 \mathrm{~nm}$ + raudona $660 \mathrm{~nm}$ + tolimoji raudona $731 \mathrm{~nm}$; L7 - mèlyna $445 \mathrm{~nm}$ + raudona $638 \mathrm{~nm}$ + raudona $669 \mathrm{~nm}$ + tolimoji raudona $731 \mathrm{~nm}$ + UV $385 \mathrm{~nm}$

* KO - control, without lighting; LO - fluorescent lamp; L1 - red $638 \mathrm{~nm} ; \mathrm{L2}$ - blue $445 \mathrm{~nm}+$ red $638 \mathrm{~nm} ; \mathrm{L3}$ - blue $445 \mathrm{~nm}+$ red $638 \mathrm{~nm}+$ far red $731 \mathrm{~nm} ; \mathrm{L} 4$ - blue $445 \mathrm{~nm}+$ red $638 \mathrm{~nm}+$ red $669 \mathrm{~nm} ; \mathrm{L} 5$ - blue $445 \mathrm{~nm}+$ red $638 \mathrm{~nm}+$ red $669 \mathrm{~nm}+$ far red $731 \mathrm{~nm} ; \mathrm{L} 6$ - blue $445 \mathrm{~nm}+$ red $638 \mathrm{~nm}+$ red $660 \mathrm{~nm}+$ far red $731 \mathrm{~nm} ; \mathrm{L7}$ - blue $445 \mathrm{~nm}+$ red $638 \mathrm{~nm}+$ red $669 \mathrm{~nm}+$ far red $731 \mathrm{~nm}+$ UV $385 \mathrm{~nm}$
}

2 pav. Šviesos spektro sudèties poveikis bulvių stiebagumbių masės kitimui $2008 \mathrm{~m}$.

Fig. 2. Effect of light spectral composition on potato tuber weight loss, 2008

džiagų kaupimuisi, produktyvumui (agurkų daigams - Brazaitytè, Duchovskis, Urbonavičiūtè, 2009, salotų augimui - Urbonavičiūtè, Pinho, Samuolienė, 2007, morkų žydèjimo iniciacijai - Samuoliené, Šabajeviené, Urbonavičiūtė, 2007). Gauti tyrimų rezultatai, kurie nusako skirtingų apšvietimo derinių poveikį. Pavyzdžiui, optimaliam salotų augimui pasiekti nustatytas raudonos ir mélynos spalvų derinys (Urbonavičiūtè, Pinho, Samuolienė, 2007), tačiau bulvių daiginimas, naudojant kietakūnị apšvietimą, tirtas pirmą kartą.

Bulvès stiebagumbis yra modifikuotas stiebas, turintis tą pačią struktūrą, kaip ir antžeminis stiebas (Shpaar, Bykin, Dreger i dr., 2004). Šviesa teigiamai paveikė bulvių stiebagumbius, todèl susiformavo trumpi, tvirti pumpurai. Iš gautų tyrimo rezultatų matyti, kad kietakūnio apšvietimo deriniai skirtingai veike bulvių stiebagumbių dygimą. Apšvietimui panaudojus UV $385 \mathrm{~nm}$ spindulius nustatytas mažiausias bendras sudygusių pumpurų skaičius. Tamsoje laikytų bulvių stiebagumbių pumpurai buvo ištįsę, trapūs, daugiausia sudygusių pumpurų nustatyta viršutinèje stiebagumbių dalyje.

Angliavandeniai, ypač gliukozė ir fruktozè, turi didelę ịtaką augalo struktūrų formavimuisi ir ląstelių bei viso organizmo metabolizmui. Jie dalyvauja augalui reaguojant i aplinkos sąlygas, kaip signalą perduodančios moleku- lès, aktyvuojančios savitus hormoninių ir nehormoninių signalų perdavimo kelius, lemiančius svarbias genų ekspresijos modifikacijas ir fermentų aktyvumą (Smeekens, 2000). Pagal nustatytą sacharidų kieki skirtingose stiebagumbių zonose galime daryti išvadą, kad didžiausias jų kiekis iš dalies atitiko stiebagumbių dygimo tendencijas. Nors sacharidų signalų perdavimo ir genų ekspresijos mechanizmai nèra visiškai ištirti, atrodo, kad jie palaiko su biosinteze ir rezervų kaupimusi susijusių genų raišką ir slopina genus, atsakingus už atsargų metabolizmą (Ho, Chao, Tong et al., 2001).

Literatūroje nurodoma, kad geriausias būdas ịveikti apikalinị dominavimą ir paskatinti šoninių akelių dygimą yra prailginti stiebagumbių laikymo trukmę iki kol pasibaigs apikalinio dominavimo periodas. Kiti autoriai (Shpaar, Bykin, Dreger i dr., 2004) teigia, kad pašalinus, pavyzdžiui, nulaužus dominuojantị pumpurą, suaktyvėja kitų dygimas, tačiau toks stiebagumbio dygimo skatinimas neigiamai veikia pati stiebagumbị, kadangi šis praranda drègmę, energiją, vysta.

Tyrimų duomenimis, nustatytas apikalinio dominavimo slopinimas, kai apšvietimui komponuotas raudonų 638, $669 \mathrm{~nm}$ bei mèlynos $445 \mathrm{~nm}$ šviesų derinys (L4). Galima daryti prielaidą, kad toks apšvietimas galëjo keisti fitohormonų santyki, skatinti stiebagumbio pumpurų dygimą. 
3 lentelè. Šviesos spektro sudèties poveikis bulvių stiebagumbių sacharidų kiekiui pumpuruose bei pumpurų zonose $2008 \mathrm{~m}$.

Table 3. Effect of light spectral composition on potato tuber sugar content in the buds and bud areas, 2008

\begin{tabular}{|c|c|c|c|c|c|}
\hline \multirow{2}{*}{$\begin{array}{l}\text { Apšvietimo derinys } \\
\text { Combination of } \\
\text { lighting }\end{array}$} & \multirow{2}{*}{$\begin{array}{c}\text { Stiebagumbio zona } \\
\text { Tuber part }\end{array}$} & \multicolumn{4}{|c|}{ Sacharidų kiekis $\mathrm{mg} \mathrm{g}^{-1} /$ Saccharide content, $\mathrm{mg} \mathrm{g}^{-1}$} \\
\hline & & $\begin{array}{l}\text { Fruktozè } \\
\text { Fructose }\end{array}$ & $\begin{array}{l}\text { Gliukozè } \\
\text { Glucose }\end{array}$ & $\begin{array}{l}\text { Sacharozè } \\
\text { Saccharose }\end{array}$ & $\begin{array}{l}\text { Maltozè } \\
\text { Maltose }\end{array}$ \\
\hline \multirow{3}{*}{$\begin{array}{c}\text { Tamsa } \\
\text { Without lighting }\end{array}$} & $\begin{array}{c}\text { Apikalinis pumpuras } \\
\text { Apical bud }\end{array}$ & $4,55 \pm 0,30$ & $21,78 \pm 0,92$ & $2,55 \pm 1,00$ & $0,65 \pm 0,14$ \\
\hline & $\begin{array}{l}\text { Apikalinè zona } \\
\text { Apical part }\end{array}$ & $1,56 \pm 0,15$ & $5,31 \pm 0,44$ & $2,14 \pm 0,04$ & $0,26 \pm 0,003$ \\
\hline & $\begin{array}{c}\text { Šoninè zona } \\
\text { Lateral part }\end{array}$ & $0,82 \pm 0,01$ & $1,07 \pm 0,09$ & $0,86 \pm 0,007$ & $0,44 \pm 0,03$ \\
\hline \multirow{3}{*}{$\begin{array}{c}\begin{array}{c}\text { Fluorescencinè } \\
\text { lempa }\end{array} \\
\text { Fluorescent lamp }\end{array}$} & $\begin{array}{c}\text { Apikalinis pumpuras } \\
\text { Apical bud }\end{array}$ & $2,82 \pm 0,11$ & $1,14 \pm 0,06$ & $1,14 \pm 0,07$ & - \\
\hline & $\begin{array}{c}\text { Apikalinė zona } \\
\text { Apical part }\end{array}$ & - & $2,24 \pm 0,01$ & $0,49 \pm 0,03$ & - \\
\hline & $\begin{array}{l}\text { Šoninė zona } \\
\text { Lateral part }\end{array}$ & $2,11 \pm 0,15$ & $0,60 \pm 0,09$ & $1,12 \pm 0,08$ & - \\
\hline \multirow{3}{*}{$638 \mathrm{~nm}$} & $\begin{array}{c}\text { Apikalinis pumpuras } \\
\text { Apical bud }\end{array}$ & $1,13 \pm 0,08$ & $2,95 \pm 0,09$ & $2,18 \pm 0,03$ & - \\
\hline & $\begin{array}{l}\text { Apikalinè zona } \\
\text { Apical part }\end{array}$ & $0,62 \pm 0,01$ & $0,69 \pm 0,06$ & - & - \\
\hline & $\begin{array}{l}\text { Šoninè zona } \\
\text { Lateral part }\end{array}$ & $2,90 \pm 0,23$ & $0,48 \pm 0,01$ & $1,16 \pm 0,12$ & - \\
\hline \multirow{3}{*}{$638,445 \mathrm{~nm}$} & $\begin{array}{c}\text { Apikalinis pumpuras } \\
\text { Apical bud }\end{array}$ & $1,99 \pm 0,17$ & $5,54 \pm 0,25$ & $2,51 \pm 0,01$ & $1,13 \pm 0,02$ \\
\hline & $\begin{array}{l}\text { Apikalinè zona } \\
\text { Apical part }\end{array}$ & $0,06 \pm 0,01$ & - & - & - \\
\hline & $\begin{array}{l}\text { Šoninè zona } \\
\text { Lateral part }\end{array}$ & $0,09 \pm 0,009$ & - & $0,11 \pm 0,002$ & - \\
\hline \multirow{3}{*}{$638,445,731 \mathrm{~nm}$} & $\begin{array}{c}\text { Apikalinis pumpuras } \\
\text { Apical bud }\end{array}$ & $0,86 \pm 0,01$ & $0,32 \pm 0,04$ & $2,33 \pm 0,06$ & $0,59 \pm 0,02$ \\
\hline & $\begin{array}{l}\text { Apikalinè zona } \\
\text { Apical part }\end{array}$ & $0,93 \pm 0,01$ & $1,83 \pm 0,21$ & $0,37 \pm 0,06$ & $0,58 \pm 0,03$ \\
\hline & $\begin{array}{c}\text { Šoninè zona } \\
\text { Lateral part }\end{array}$ & $0,51 \pm 0,01$ & $1,42 \pm 0,02$ & $0,48 \pm 0,04$ & $0,20 \pm 0,06$ \\
\hline \multirow{3}{*}{$638,669,445 \mathrm{~nm}$} & $\begin{array}{c}\text { Apikalinis pumpuras } \\
\text { Apical bud }\end{array}$ & $0,49 \pm 0,08$ & $0,65 \pm 0,009$ & $0,22 \pm 0,03$ & - \\
\hline & $\begin{array}{l}\text { Apikalinè zona } \\
\text { Apical part }\end{array}$ & $0,37 \pm 0,01$ & $0,19 \pm 0,06$ & $0,14 \pm 0,04$ & $0,55 \pm 0,01$ \\
\hline & $\begin{array}{l}\text { Šoninè zona } \\
\text { Lateral part }\end{array}$ & $0,32 \pm 0,07$ & $0,36 \pm 0,06$ & $0,15 \pm 0,04$ & $0,13 \pm 0,03$ \\
\hline \multirow{3}{*}{$\begin{array}{c}638,669,731 \\
445 \mathrm{~nm}\end{array}$} & $\begin{array}{c}\text { Apikalinis pumpuras } \\
\text { Apical bud }\end{array}$ & $3,21 \pm 0,13$ & $7,66 \pm 0,59$ & $3,74 \pm 0,01$ & $0,88 \pm 0,02$ \\
\hline & $\begin{array}{l}\text { Apikalinè zona } \\
\text { Apical part }\end{array}$ & $1,60 \pm 0,18$ & $2,85 \pm 0,06$ & $1,46 \pm 0,02$ & $0,06 \pm 0,002$ \\
\hline & $\begin{array}{l}\text { Šoninè zona } \\
\text { Lateral part }\end{array}$ & $1,83 \pm 0,05$ & $6,31 \pm 0,29$ & $2,06 \pm 0,42$ & $0,99 \pm 0,02$ \\
\hline \multirow{3}{*}{$\begin{array}{c}638,660,731 \\
445 \mathrm{~nm}\end{array}$} & $\begin{array}{l}\text { Apikalinis pumpuras } \\
\text { Apical bud }\end{array}$ & $2,26 \pm 0,07$ & $3,83 \pm 0,05$ & $2,86 \pm 0,02$ & $1,08 \pm 0,03$ \\
\hline & $\begin{array}{l}\text { Apikalinè zona } \\
\text { Apical part }\end{array}$ & $1,10 \pm 0,17$ & $0,20 \pm 0,001$ & $0,30 \pm 0,05$ & - \\
\hline & $\begin{array}{l}\text { Šoninè zona } \\
\text { Lateral part }\end{array}$ & $1,00 \pm 0,20$ & $1,50 \pm 0,04$ & $0,97 \pm 0,03$ & - \\
\hline \multirow{3}{*}{$\begin{array}{c}638,669,731,445 \\
\text { UV } 385 \mathrm{~nm}\end{array}$} & $\begin{array}{l}\text { Apikalinis pumpuras } \\
\text { Apical bud }\end{array}$ & $4,65 \pm 1,35$ & $10,19 \pm 0,16$ & $4,27 \pm 0,21$ & $0,46 \pm 0,30$ \\
\hline & $\begin{array}{l}\text { Apikalinè zona } \\
\text { Apical part }\end{array}$ & $1,28 \pm 0,15$ & $3,24 \pm 0,10$ & $1,22 \pm 0,01$ & $0,60 \pm 0,03$ \\
\hline & $\begin{array}{l}\text { Šoninè zona } \\
\text { Lateral part }\end{array}$ & $0,71 \pm 0,01$ & $0,60 \pm 0,04$ & $0,88 \pm 0,06$ & - \\
\hline
\end{tabular}




\section{IŠVADOS}

1. Komponenčiu derinys - raudonos $638 \mathrm{~nm}$, mèlynos $445 \mathrm{~nm}$ bei tolimosios raudonos $731 \mathrm{~nm}$ - skatino didžiausią bulvių stiebagumbių pumpurų dygimą (94,40\%), sudygusių pumpurų skaičius $37 \%$ didesnis nei tamsoje laikytų stiebagumbių.

2. Šviesos spektro sudèties poveikis bulvių stiebagumbių apikalinio dominavimo slopinimui nustatytas didžiausias, kai daiginimui naudotas raudonų 638 ir $669 \mathrm{~nm}$ su mèlyna $445 \mathrm{~nm}$ komponenčių derinys (L4). Viršutinèje stiebagumbio dalyje pumpurų sudygo $30 \%$ mažiau, vidurinëje dalyje $-21 \%$ daugiau, o apatinèje dalyje $-8 \%$ daugiau nei tamsoje laikytu (palyginamujjų) stiebagumbių.

3. Daugiausia sacharidų $\left(\sim 30 \mathrm{mg} \mathrm{g}^{-1}\right)$ apikaliniuose pumpuruose sukaupe tamsoje laikyti bulvių stiebagumbiai ir stiebagumbiai, kurie buvo švitinti komponenčiu deriniu: raudonų $638,669 \mathrm{~nm}$, tolimosios raudonos $731 \mathrm{~nm}$ bei mélynos $445 \mathrm{~nm}$, papildytu UV $385 \mathrm{~nm}$ (L7) spinduliais. Tačiau sudygusių pumpurų buvo $10 \%$ mažiau nei palyginamųjų stiebagumbių.

Gauta 20110310 Priimta 20110411

\section{Literatūra}

1. Allen E. J., O’Brien P. J., Firman D. 1992. Seed tuber production and management. In: Harris P. M. (ed.). The Potato Crop. The Scientific Basis for Improvement. 2nd edn. London. P. 247-291.

2. Bliznikas Z., Breivè K., Tamulaitis G. ir kt. 2004. Puslaidininkè lempa augalų fotofiziologiniams procesams tirti ir valdyti. Elektronika ir elektrotechnika. Nr. 7(56). P. 74-79.

3. Brazaitytė A., Duchovskis P., Urbonavičiūtė A. ir kt. 2009. The effect of light-emitting diodes lighting on cucumber transplants and after-effect on yield. Zemdirbyste-Agriculture. Vol. 96. No. 3. P. 102-118.

4. Dougher T. A., Bugbee B. G. 1998. Is blue light good or bad for plants? Life Support \& Biosphere Science. Vol. 5. P. 129-136.

5. Fernie A. R., Willmitzer L. 2001. Molecular and biochemical triggers of potato tuber development. Plant Physiology. Vol. 127. P. 1456-1465.

6. Furuya M. 1993. Phytochromes: their molecular species, gene families, and functions. Annual Review of Plant Physiology. Vol. 44. P. 617-645.

7. Grigoriadou K., Leventakis N. 1999. Large scale commercial production of potato minitubers, using in vitro techniques. Potato Research. Vol. 42. P. 607-610.

8. Hare P. D., Cress W. A., Van Staden J. 1999. Proline synthesis and degradation: a model system for elucidating stress-related signal transduction. Journal of Experimental Botany. Vol. 50. P. 413-434.

9. Heo J., Lee C., Chakrabarty D. et al. 2002. Growth responses of marigold and salvia bedding plants as affected by monochromic or mixture radiation provided by a LightEmitting Diode (LED). Plant Growth Regulation. Vol. 38. P. 225-230.

10. Ho S. L., Chao Y. C., Tong W. F. et al. 2001. Sugar coordinately and differentially regulates growth- and stress related gene expresion via a conylex signal transduction network and multiple control mechanisms. Plant Physiology. Vol. 125. P. 877-890.

11. Lazauskas J., Ražukas A. 2001. Bulvininkyste Lietuvoje 1900-2000 m. Vilnius. P. 78-80.

12. Lin C. 2002. Blue light receptors and signal transduction. The Plant Cell. P. 207-225.

13. O'Brien P. J., Allen E. J. 1992. Effects of seed crop husbandry, seed source, seed tuber weight and seed rate on the growth of ware potato crops. Journal of Agricultural Science. Vol. 119. P. 355-366.

14. Rodiklių duomenų bazè. 2010. Statistikos departamentas prie Lietuvos Respublikos Vyriausybès [žiūrèta 201011 15]. Prieiga per internetą: http://dbl.stat.gov.lt/ statbank/default.asp? $w=1280$

15. Samuolienė G., Šikšnianienè J. B., Duchovskis P. ir kt. 2004. Šviesos kokybės ịtaka valgomụjų morkų fiziologiniams procesams evokacijos bei žiedų iniciacijos tarpsniais. Sodininkystè ir daržininkystè. Vol. 23(1). P. 78-87.

16. Samuolienė G., Šabajevienè G., Urbonavičiūtè A. et al. 2007. Carrot flowering initiation: light effect, photosynthetic pigments, carbohydrates. Acta Biologica Szegediensis. Vol. 51(1). P. 39-42.

17. Schuerger A. C., Brown C. S., Stryjewski E. C. 1997. Anatomical features of pepper plants (Capsicum annum L.) grown under red light-emitting diodes supplemented with blue or far-red light. Annals of Botany. Vol. 79. P. 173-282.

18. Smeekens S. 2000. Sugar-induced signal transduction in plants. Anual Review of Plant Physiology and Plant Molecular Biology. Vol. 161. P. 551-555.

19. Šlapakauskas V., Duchovskis P. 2008. Augalu produktyvumas. Kaunas. P. 201-204.

20. Tarakanovas P., Raudonius S. 2003. Agronominiu tyrimu duomeny statistine analize taikant kompiuterines programas ANOVA, STAT, SPIT PLOT iš paketo SELEKCIJA ir IRRISTAT. Akademija. P. 5-10.

21. Urbonavičiūtè A., Pinho P., Samuolienė G. ir kt. 2007. Effect of short-wavelength light on lettuce growth and nutritional quality. Sodininkyste ir daržininkystè. Vol. 26(1). P. 157-165.

22. Shpaar D., Bykin A., Dreger D. i dr. 2004. Kartofel. Pod red. D. Shpaara. Torzhok: OOO „Variant“. 466 p. 
Živilè Juknevičienè, Giedrè Samuolienè, Akvilè Viršilè, Pavelas Duchovskis, Egidija Venskutonienè

THE EFFECT OF LIGHT SPECTRAL COMPOSITION ON APICAL DOMINANCE ELIMINATION IN POTATO (SOLANUM TUBEROSUM L.) TUBER

Summary

Vegetative experiments were carried out in a phytotron complex at the Laboratory of Plant Physiology, Institute of Horticulture, Lithuanian Research Centre for Agriculture and Forestry in 2008. The investigation was focused on Solanum tuberosum L. var. 'Solara'. Twenty-one days before planting, potato tubers had been illuminated with the basal red $638 \mathrm{~nm}$ light emitting diodes supplemented with 445, 660, 669, 731, UV $385 \mathrm{~nm}$ components and then with high-pressure sodium lamps. Reference potato tubers were stored in the phytotron chamber without light. To assess the impact of solid-state lighting spectral composition on the germination of potato tubers, the quantitative method was applied to determine the number and percentage of germinated shoots in the upper, middle and bottom parts of tubers, the weight of tubers ( $\mathrm{g}$ and \%), sugar content and composition in potato tuber shoots and in shoot areas.

Studies have shown a positive effect of the spectral composition of light on potato tuber germination. Irradiated tubers shaped short, compact buds. If potato tubers were kept in the dark, their buds were pale yellow in colour and brittle. The greatest inhibition of apical domination in potato tubers was observed at the solidstate lighting spectral composition of blue $445 \mathrm{~nm}$, red $638 \mathrm{~nm}$ and red $669 \mathrm{~nm}$ (L4) light. The total maximum number (94.40\%) of germinated shoots was observed at the solid-state lighting spectral composition of blue $445 \mathrm{~nm}$ and red $638 \mathrm{~nm}$ light (L3). The impact on the germination of potato tubers was negative at the solid-state lighting composition with UV $385 \mathrm{~nm}$.

A higher sugar content was found in the apical buds of tubers that had been kept in the dark because of a more intensive transport of assimilates. Sugar content in buds and bud growing areas directly depended on the intensity of sprouting.

Key words: potatoes, tubers, combination of lighting, apical dominance, buds, sugars 